\title{
SARS-CoV-2 pandemic: causes and current situation, historical lessons, and strategical therapeutic interventions
}

\author{
Muhammad Adnan Shereen ${ }^{1}$, Abeer Kazmi ${ }^{2, *}$
}

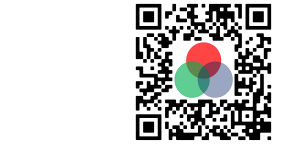

Use your smartphone to scan this QR code and download this article

\begin{abstract}
The severe acute respiratory syndrome coronavirus 2 (SARS-CoV-2), which caused an initial outbreak in China, now has 40 strains with infections in more than 200 countries worldwide, according to scientists. To date, 4,121,777 people have become infected and 280,868 people died as a result of coronavirus disease 2019 (COVID-19), with many patients still under critical condition. The SARS-CoV-2 is phylogenetically similar to SARS-like bat viruses and, thus, bats can be a key host for SARS-CoV-2. Many viruses have been transmitted to humans due to the consumption of wild birds and animals as a food source. The lack of vaccine, improper containment, and diagnostic strategies by various countries have converted COVID-19 into a global pandemic. The lockdown conditions in developing countries may produce economic crises. COVID-19 patients can suffer from mental distress, partly resulting from quarantine restrictions, and therefore, there is dire need for mental counseling. The combination of previously used broad-spectrum antibiotics, antiviral and anti-parasite agents, and interferon have reduced viral infection at higher and frequent doses. Many patients have been discharged after clinical recovery, though COVID-19 can still leave severe adverse effects on $\mathrm{p}$ atients. The use of traditional Chinese medicines (TCMs) has led to recovery of $90 \%$ of COVID-19 patients in China. The current review article highlights the current situation, the major causes which have led to the COVID-19 pandemic, as well as strategical interventions to control the pandemic and cure infected patients.

Key words: SARS-CoV-2, COVID-19, epidemic, pandemic
\end{abstract}

${ }^{1}$ State Key Laboratory of Virology, College of Life Sciences, Wuhan University, Wuhan, PR China

${ }^{2}$ College of Life Sciences, Wuhan University, Wuhan, PR China

\section{Correspondence}

Abeer Kazmi, College of Life Sciences, Wuhan University, Wuhan, PR China

Email: Abeer_Kazmi@yahoo.com

\section{History}

- Received: May 11, 2020

- Accepted: May 24, 2020

- Published: May 28, 2020

DOI : 10.15419/bmrat.v7i5.608

\section{Check for updates}

\section{Copyright}

( ) Biomedpress. This is an openaccess article distributed under the terms of the Creative Commons Attribution 4.0 International license.

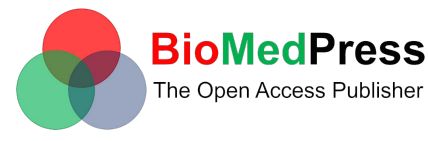

\section{INTRODUCTION}

When an emerging epidemic in a region or country is not actively controlled, and spreads widely to other areas, it becomes pandemic. In history, the world has witnessed numerous epidemics which have turned into pandemics because of failure in quick response action. In some cases, treatment and vaccines are not available at the time. Thus, controlling the wide spread of infection, effective quarantine, proper diagnosis, hospitalization, and safety measures are key factors to successful deal with the epidemic.

Infectious diseases have long been the cause of global pandemics. The first time the quarantine strategy was used to control infectious disease outbreak was in Italy (and followed by other countries) during the Black Death in $1346^{1}$. Moreover, this was one of the top worst outbreaks in history; it was an epidemic caused by Yersinia pestis (bacteria) in China and Russia during the spring season of 1346, which later developed into a pandemic and became known as the "Black Death". Of note, 75 million people died from the Black Death in Europe and Asia ${ }^{2}$. Later on, another epidemic, named as "smallpox" and caused by variola virus, became pandemic and killed 2 million people ${ }^{3}$. Moreover, while various strains of influenza virus still infect millions of people around the world today, the major flu-related pandemic (termed the "Spanish flu") initiated in 1918 and infected 500 million individuals, with 30 million deaths across the globe ${ }^{4}$. Human immunodeficiency virus (HIV) which causes acquired immunodeficiency syndrome (AIDS) emerged during 1920 in Africa; it later spread worldwide. HIV still infects people in many countries including, Canada, India, United States, Mexico, Germany, Brazil, Indonesia and Iran. To date, HIV has infected 75 million people; 32 million have died and many are still dying each year ${ }^{5,6}$. The details of viruses which have previously caused global pandemics and which are still infecting world population are outlined in Table 1.

\section{STATUS OF COVID-19}

History indeed repeats itself. Recently, in the $21^{\text {st }}$ century, another epidemic broke out, this time caused by severe acute respiratory syndrome coronavirus 2 (SARS-CoV-2) and originating from the Hunan Seafood Wholesale Market, in Wuhan, China. This 
Table 1: The comparative analysis of SARS-CoV-2 with previous pathogens that caused the worst pandemics in history

\begin{tabular}{|c|c|c|c|c|c|}
\hline Parameters & HIV & $\begin{array}{l}\text { Influenza } \\
\text { virus }\end{array}$ & $\begin{array}{l}\text { Variola } \\
\text { virus }\end{array}$ & $\begin{array}{l}\text { Yersinia pestis (Bacte- } \\
\text { ria) }\end{array}$ & SARS-CoV-2 \\
\hline $\begin{array}{l}\text { Emergence } \\
\text { date }\end{array}$ & 1920 & 1918 & 1350 & 1346 & $\begin{array}{l}\text { December, } \\
2019\end{array}$ \\
\hline $\begin{array}{l}\text { Area of emer- } \\
\text { gence }\end{array}$ & $\begin{array}{l}\text { Central and West } \\
\text { Africa }\end{array}$ & $\begin{array}{l}\text { France, } \\
\text { Spain }\end{array}$ & $\begin{array}{l}\text { Africa, In- } \\
\text { dia, Europe }\end{array}$ & China, Russia & Wuhan, China \\
\hline Key hosts & $\begin{array}{l}\text { Non-human pri- } \\
\text { mates }\end{array}$ & Avian origin & $\begin{array}{l}\text { African } \\
\text { rodents }\end{array}$ & Rats & Bat \\
\hline $\begin{array}{l}\text { Sign and } \\
\text { symptoms }\end{array}$ & $\begin{array}{l}\text { Fever, Chills, Rash, } \\
\text { Night sweats, Mus- } \\
\text { cle aches, Sore } \\
\text { throat, Fatigue, } \\
\text { Swollen lymph } \\
\text { nodes, Mouth } \\
\text { ulcers }\end{array}$ & $\begin{array}{l}\text { fatigue, body } \\
\text { aches, and } \\
\text { chills, cough, } \\
\text { sore throat, } \\
\text { fever }\end{array}$ & $\bullet$ & $\begin{array}{l}\text { Fever, extreme weakness, } \\
\text { abdominal pain, diar- } \\
\text { rhea, vomiting. } \\
\text { Bleeding from mouth, } \\
\text { nose, rectum, skin, } \\
\text { Blackening, and death of } \\
\text { tissue }\end{array}$ & $\begin{array}{l}\text { Cough, fever, } \\
\text { and shortness } \\
\text { of breath }\end{array}$ \\
\hline $\begin{array}{l}\text { Outbreak } \\
\text { /Disease } \\
\text { caused }\end{array}$ & AIDS & Spanish flu & Smallpox & The Black Death & $\begin{array}{l}\text { SARS, } \\
\text { COVID-19 }\end{array}$ \\
\hline $\begin{array}{l}\text { Total infected } \\
\text { patients }\end{array}$ & 75 million & 500 million & 15 million & - & $4,121,777$ \\
\hline $\begin{array}{l}\text { Total died pa- } \\
\text { tients }\end{array}$ & 32 million & 30 million & 2 million & 75 million & 280,868 \\
\hline
\end{tabular}

epidemic has also turned into a pandemic. SARSCoV-2 induces pneumonia in humans; the disease is referred to as corona virus disease of 2019 (i.e. COVID-19) and is similar to the previous SARS-CoV disease (2002), which originated from bats ${ }^{7}$.

Several factors have led to the wide spread of SARSCoV-2, including the use of wild animals as a food source, large and public gatherings, poor quarantine, and inadequate containment and tracing strategies. The factors and mechanisms of infectious spread are explained in Figure 1. The total number of confirmed infected cases of SARS-CoV-2 are 82,901, with more than 4,633 mortalities recorded in China; indeed, a total of 4,121,777 confirmed cases and 280,868 fatalities were documented in more than 190 countries at the time of this article was written (May 10 ${ }^{t h}, 2020$ ) (Table 1$)^{9-12}$. At the current time, USA is the country with the most infections $(1,347,318$ infected people and 80,040 deaths; $6 \%$ mortality rate), followed by France (14.9\% mortality rate), UK (14.5\% mortality rate), Italy (13.9\% mortality rate), and Spain (10.1\% mortality rate $)^{10}$.

\section{USE OF WILD ANIMALS AS SOURCE OF FOOD AND EMERGENCE OF HANTAVIRUS}

At the time of the SARS-CoV-2 pandemic situation happening around the world, another virus termed Hantavirus emerged and killed one person on the way traveling to Shandong (China). The Hantavirus case reported in China amid the COVID-19 pandemic created more panic among people worldwide and became one of the top trends on social media. Recently, a person from Lincang city of Yunnan province died on March $23^{r d}, 2020$. This person was found to be negative for SARS-CoV-2 (COVID-19 disease) but positive for Hantavirus ${ }^{13}$.

Rodents can be key hosts and transmission sources for viruses. Several Hantavirus outbreaks have been reported previously and have infected many people in the USA and other regions of the world. Currently, there is no FDA approved antiviral or vaccine that is available to treat Hantavirus infection, just as is the case for COVID-19. The infection can be caused by eating rodents, or from rodent bites or exposure to rodent blood, saliva, or feces and fumes ${ }^{14,15}$. The human-to-human transmission of the virus is very rare, although there have been a 


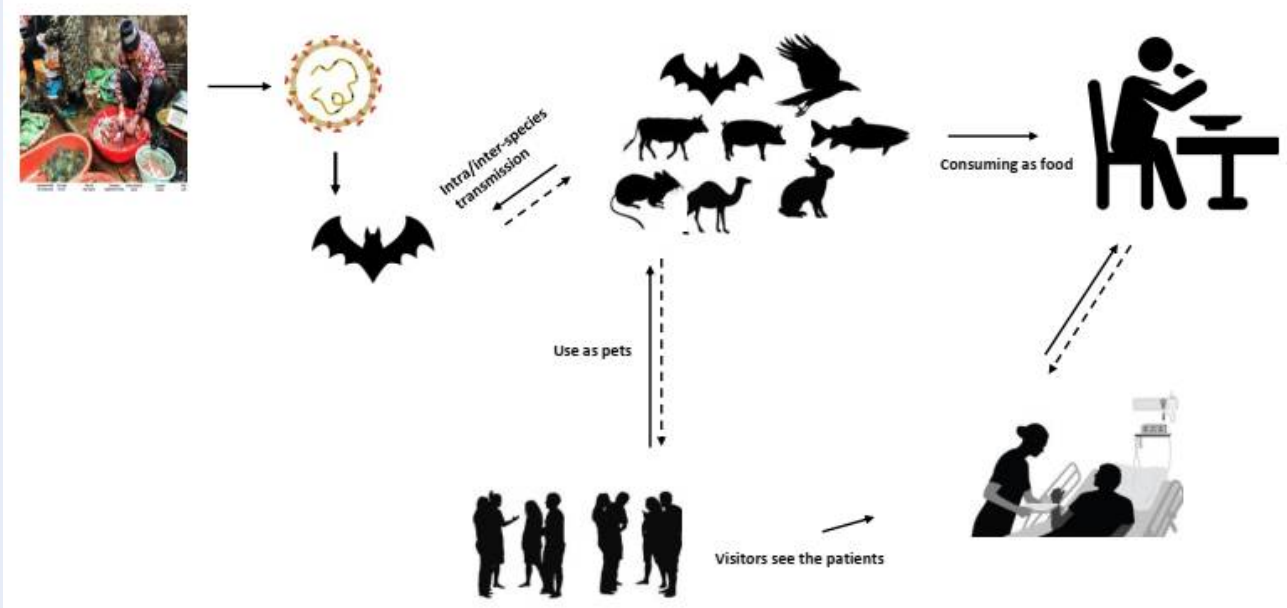

Figure 1: The emergence of SARS-CoV-2 and mechanism of transmission from an animal host to human and human to human ${ }^{8}$. The Figure has been modified.

few reports which have indicated human-to-human transmission of Hantavirus ${ }^{16,17}$.

Therefore, Chinese researchers and the Chinese government have advised keeping an eye on the Yunnan region and especially those regions where the number of rodents are high. The human-to-human transmission of Hantavirus is not common, although much is still unclear. There may be the possibility of mutation in strains of Hantavirus which may enhance the person-to-person transmission affinity, as there were mutational changes reported in SARS-CoV-2 which promoted the pandemic. Since wild animals are key reservoirs for many viruses and other pathogens, the Chinese and Korean governments should strictly impose a ban on consumption of rodents and other wild animals as a source of food.

\section{REASON OF VIRAL SPREADING IN REST OF THE WORLD}

The main reason behind the viral transmission in many countries is due to the evacuation of their nationals from the epicenter of SARS-CoV-2 (Wuhan, China) without proper screening and quarantine procedure. The individuals traveled from infected countries were not fully aware of or underestimated the risk of viral transmission ${ }^{18}$. Isolation wards for confirmed infected patients near the quarantine centers of suspected people (or people coming from infected areas) could further limit the risk for exposure to infected patients. Residents from countries like Pakistan, Bangladesh, India, Afghanistan, and Iran typically already have strong immune systems, often ac- quired in the state of war, against common pneumonia, HIV, flu, and other endemics/epidemics. These countries also face poverty, political instability, terrorism, and lack of diagnostic and research laboratories which limit public health resources. Moreover, infectious viruses are also frequently mutating and adapting to the environment, thereby enhancing viral pathogenicity, which have led to worsening conditions in Europe and the US. To date, 40 strains of a single SARS-CoV-2 have been discovered across the globe ${ }^{11}$.

\section{THERAPEUTIC STRATEGIES}

At present, no specific vaccine or anti-viral drug is available to treat COVID-19, though the combination of anti-viral and anti-bacterial drugs, as well as inhibitors, have significantly reduced the viral load in infected patients and animal models ${ }^{19}$. High doses of Remdesivir, Chloroquine salts, Arbidol, Nafamostat, Nitazoxanide, Ribavirin, Penciclovir, Favipiravir, Ritonavir and Baricitinib, either alone or in combination, have efficiently reduced viral load in infected patients ${ }^{8,20,21}$. High dose of antiviral and antibiotics have help patients to recover from COVID-19 but have also caused severe adverse effects in elderly patients. Higher doses of antiviral agents have caused mental, hepatic, cardiac and renal complications in many patients ${ }^{22-24}$. Plasma isolated from recovered patients have also been used to treat infected patients, resulting in production of antibodies against SARSCoV-2 and clinical recovery of infected patients ${ }^{25}$. 


\section{MENTAL COUNSELING AND RAPID DIAGNOSIS}

Those who have been kept in quarantine phase can often suffer from the unpleasant experience. Separation from family and loved ones, and loss of freedom can cause psychological effects. In a previous outbreak, suicides during quarantine were reported ${ }^{26}$. To minimize the negative effects of quarantine, the phase should be reduced as much as possible. The lack of a sensitive and rapid diagnosis of COVID-18 has caused a prolonged quarantine phase for suspected patients. Mental illnesses can lead to weaker immunity, which in turn enhances the chance of being infected $^{27}$, and can be related to morbidity and mortality. Indeed, the limited exposure to outside environment, lost income, limited access to masks and other preventive measures, fear of contracting the infection, and lack of facilities have fueled the severity of mental illnesses and led to many people suffering from xenophobia $^{28}$. Many individuals have faced altered and negative behaviors, such as rudeness, anger and frustration, due to constant exposure to electronic devices and disturbed circadian cycle ${ }^{29}$. Thus, mental counseling and support for medical health workers, patients in quarantine or isolation phase, and people during lockdown are not only highly recommended but necessary.

After the emergence of SARS-CoV-2, a real-time reverse transcriptase-polymerase chain reaction (RTPCR) test has been consistently used for the detection of the virus, although it is not possible to carry out RT-PCR at people's doorsteps to conduct door-todoor detection. Currently, antibody-based (IgM-IgG) - immunochromatographic test kits (ICT Kits) ${ }^{30}$ and droplet digital-polymerase chain reaction (dd-PCR) have shown promising sensitive and accurate results for the detection of SARS-CoV-2 ${ }^{31}$. ICT kits are smaller in size and can provide rapid results. Therefore, use of ICT kits can be an effective tool for doorto-door and maximal detection of COVID-19 patients.

\section{VACCINES AND TRADITIONAL CHINESE MEDICINES (TCMS)}

Vaccines are the most effective and suitable solution to treat and eradicate viral infections. Unfortunately, at the current time, there is no vaccine available to treat human coronaviruses, especially SARS-CoV-2 induced COVID-19. However, some multinational pharmaceutical companies and research centers, including Johnson \& Johnson, Stemirna Therapeutics,
US National Institute of Allergy and Infectious Diseases, Novavax, and Sanofi are making efforts to develop an effective vaccine for COVID-19 ${ }^{32-34}$. The mortality rate from COVID-19 is steadily increasing around the world, but these companies and research centers still require 5 to 10 months to develop a vaccine. There is still doubt as to whether these vaccines will be effective against all the existing strains of SARS-CoV-2. In a recent report, the Chinese have developed a vaccine called PiCoVacc which was successful in animal trials; however, it was effective against only 10 strains of SARS-CoV-2 ${ }^{35}$.

Nature has the best remedy for microbial infections. Plants which exist in nature contain various plant-specific secondary metabolites which can have robust bioactivities including anticancer, antiinflammatory, antiviral, antibacterial and antidiabetic functions ${ }^{36,37}$. Traditional Chinese medicines (TCMs) are a complex mixture of diverse medicinal plants (herbs) and widely used in China for the treatment of a variety of diseases including viral and bacterial infections. TCMs have been the most effective therapeutic strategy for the avan flu, influenza, HCV, HBV, SARS and MERS-CoV outbreaks in China ${ }^{38}$. The Chinese health workers have claimed that more than $91 \%$ of COVID-19 patients have clinically recovered from use of TCMs ${ }^{39}$. Of note, COVID-19 patients with highly critical conditions have only been treated with Sheng Mai injection, or An Gong Niu Huang and Su He Xiang tablets; patients with mild to moderate conditions have been treated with Qing Fei Pai Du Tang, Huo Xiang Zheng Qi Shui, Xi Yan Ping, Xue Bi Jing, Re Du Ning, Tan Re Qing, and Xing Nao Jing injection ${ }^{12,40,41}$.

\section{CONCLUSION AND FUTURE PROSPECTS}

The SARS-CoV-2 outbreak first initiated in China but has now spread to every country of the world. USA and European countries have become the new epicenter of COVID-19. The European countries responded late and their nationals did not effectively follow the strategies to contain the virus. Therefore, the mortality rate from COVID-19 in Europe is almost 15\%, while in China the mortality rate has been limited to $4 \%$. Chinese health authorities responded swiftly and effectively to contain the viral spreading and treated their patients with TCMs, which resulted in greater than $91 \%$ recovery.

We suggest that the higher authorities of infected countries take serious action in conducting awareness campaigns to educate their nationals on how to 
best protect themselves and other people in their surroundings from the viral infection. Flight operations should be limited and the consumption of wild animals should be completely banned until the specific origin of the SARS-CoV-2 is confirmed. It is further suggested that isolation and quarantine wards for infected and suspected patients be built near the borders and airports, thereby restricting potentially infected individuals from entering populated cities. A psychiatrist along with doctors should be placed in isolation wards for the sake of mental counseling of infected and suspected persons. The most efficient strategies used by the Chinese government and doctors to contain and treat COVID-19 should be adopted by infected countries. ICT kits and dd-PCR should be commercialized and used for rapid and accurate detection to avoid delays of the quarantine phase. Use of TCMs should be encouraged to treat COVID-19 patients; moreover, evaluation of novel antiviral compounds from plants should be conducted. Lastly, we suggest that door-to-door rapid diagnosis and assessments should be a current priority in the fight against SARS-CoV-2.

\section{ABBREVIATIONS}

SARS-CoV-2: Severe acute respiratory syndrome coronavirus-2

COVID-19: Corona virus disease-2019

TCMs: Traditional Chinese medicines

HIV: Human immunodeficiency virus

AIDS: Acquired immunodeficiency syndrome

FDA: Food and Drug Administration

RT-PCR: Real-time reverse transcriptase-polymerase chain reaction

ICT Kits: Immunochromatographic test kits

\section{ACKNOWLEDGMENTS}

The authors acknowledge the Department of Microbiology and Department of Genetics, Wuhan University, China for their support.

\section{AUTHOR'S CONTRIBUTIONS}

Authors contributed equally. All authors made substantial contributions to conception and design, acquisition of data, or analysis and interpretation of data; took part in drafting the article or revising it critically for important intellectual content; gave final approval of the version to be published; and agree to be accountable for all aspects of the work.

\section{FUNDING}

Not applicable.

\section{AVAILABILITY OF DATA AND MATERIALS}

Not applicable.

\section{ETHICS APPROVAL AND CONSENT TO PARTICIPATE}

Not applicable.

\section{CONSENT FOR PUBLICATION}

Not applicable.

\section{COMPETING INTERESTS}

The authors declare that they have no competing interests.

\section{REFERENCES}

1. Newman KL. Shutt up: bubonic plague and quarantine in early modern England. Journal of social history. 2012;45(3):809-834. PMID: 22611587. Available from: https: //doi.org/10.1093/jsh/shr114.

2. Dols MW. The black death in the Middle East. Princeton University Press. 2019;Available from: https://doi.org/10.2307/ j.ctvbcd1b3.

3. Duggan AT, Perdomo MF, Piombino-Mascali D, Marciniak $\mathrm{S}$, Poinar D, Emery MV, et al. 17th century variola virus reveals the recent history of smallpox. Current Biology. 2016;26(24):3407-3412. PMID: 27939314. Available from: https://doi.org/10.1016/j.cub.2016.10.061.

4. Honigsbaum M. A history of the great influenza pandemics: death, panic and hysteria. IB Tauris. 2013;30:1830-1920.

5. Mburu G, Igbinedion E, Lim SH, Paing AZ, Yi S, Elbe S, et al. Outcomes of HIV treatment from the private sector in low-income and middle-income countries: a systematic review protocol. BMJ open. 2020;10(1):e031844. PMID: 31919124. Available from: https://doi.org/10.1136/bmjopen-2019-031844.

6. Gray F, Sharer LR. Human Immunodeficiency Virus Infection of the CNS. Infections of the Central Nervous System: Pathology and Genetics. 2020;p. 215-229. PMID: 31690980. Available from: https://doi.org/10.1002/9781119467748.ch23.

7. Cui J, Li F, Shi ZL. Origin and evolution of pathogenic coronaviruses. Nature reviews Microbiology. 2019;17(3):181-192. PMID: 30531947. Available from: https://doi.org/10.1038/ s41579-018-0118-9.

8. Shereen MA, Khan S, Kazmi A, Bashir N, Siddique R. COVID-19 infection: origin, transmission, and characteristics of human coronaviruses. Journal of Advanced Research. 2020;(24):9198. PMID: 32257431. Available from: https://doi.org/10.1016/j. jare.2020.03.005.

9. Vara V. Coronavirus outbreak: The countries affected. https ://www.pharmaceutical-technology.com/features/coronavir us-outbreak-the-countries-affected/ [cited 2020 16, March]; 2020.

10. Worldometer. COVID-19 coronavirus pandemic. https://www. worldometers.info/coronavirus/ [cited 202022 march]; 2020.

11. Nafie M. Coronavirus mutates into 40 strains. How this changes the pandemic outlook: Experts. Al-arabiya English, $\mathrm{h}$ ttps://english.alarabiya.net/en/features/2020/03/27/Coronav irus-mutates-into-40-strains-How-this-changes-the-pandemi c-outlook-Exp [cited 20205 April]; 2020.

12. Yang $Y$, Islam MS, Wang J, Li Y, Chen X. Traditional Chinese medicine in the treatment of patients infected with 2019-new coronavirus (SARS-CoV-2): a review and perspective. International journal of biological sciences. 2020;16(10):1708. PMID: 32226288. Available from: https://doi.org/10.7150/ijbs.45538. 
13. Times G. What should be known about hantavirus case in China amid COVID-19 pandemic? https://www.globaltimes. cn/content/1183640.shtml [cited 202025 March]; 2020.

14. Jonsson CB, Figueiredo LMT, Vapalahti O. A global perspective on hantavirus ecology, epidemiology, and disease. Clinical microbiology reviews. 2010;23(2):412-441. PMID: 20375360. Available from: https://doi.org/10.1128/CMR.00062-09.

15. Schmaljohn CS. Vaccines for hantaviruses: progress and issues. Expert review of vaccines. 2012;11(5):511-513. PMID 22827236. Available from: https://doi.org/10.1586/erv.12.15.

16. Goeijenbier M, Wagenaar J, Goris M, Martina B, Henttonen $H$, Vaheri $A$, et al. Rodent-borne hemorrhagic fevers: underrecognized, widely spread and preventable-epidemiology, diagnostics and treatment. Critical reviews in microbiology. 2013;39(1):26-42. PMID: 22670688. Available from: https: //doi.org/10.3109/1040841X.2012.686481.

17. Alonso DO, Pérez-Sautu U, Bellomo CM, Prieto K, Iglesias A, Coelho R, et al. Person-to-Person Transmission of Andes Virus in Hantavirus Pulmonary Syndrome, Argentina, 2014. Emerging infectious diseases. 2020;26(4):756-759. PMID: 32186494. Available from: https://doi.org/10.3201/eid2604.190799.

18. Khan S, Siddique R, Ali A, Xue M, Nabi G. Novel coronavirus, poor quarantine, and the risk of pandemic. Journal of Hospital Infection. 2020;104(4):449-450. PMID: 32057788. Available from: https://doi.org/10.1016/j.jhin.2020.02.002.

19. Wang M, Cao R, Zhang L, Yang X, Liu J, Xu M. Remdesivir and chloroquine effectively inhibit the recently emerged novel coronavirus (2019-nCoV) in vitro. Cell Research. 2020;30(3):269-271. PMID: 32020029. Available from: https: //doi.org/10.1038/s41422-020-0282-0.

20. Sheahan TP, Sims AC, Leist SR, Schäfer A, Won J, Brown AJ, et al. Comparative therapeutic efficacy of remdesivir and combination lopinavir, ritonavir, and interferon beta against MERS-CoV. Nature communications. 2020;11(1):1-14. PMID: 31924756. Available from: https://doi.org/10.1038/s41467019-13940-6.

21. Richardson P, Griffin I, Tucker C, Smith D, Oechsle O, Phelan A, et al. Baricitinib as potential treatment for 2019-nCoV acute respiratory disease. The Lancet. 2020;395(10223):e30-e31. Available from: https://doi.org/10.1016/S0140-6736(20)303044.

22. Martins AC, Cayotopa ADE, Klein WW, Schlosser AR, Silva AFD, Souza MND, et al. Side effects of chloroquine and primaquine and symptom reduction in malaria endemic area (Mâncio Lima, Acre, Brazil). Interdisciplinary perspectives on infectious diseases. 2015;2015:346853. PMID: 26357512. Available from: https://doi.org/10.1155/2015/346853.

23. Servick K. Antimalarials widely used against COVID-19 heighten risk of cardiac arrest. How can doctors minimize the danger? : Science; 2020 https://www.sciencemag.org/news/ 2020/04/antimalarials-widely-used-against-covid-19-heighte n-risk-cardiac-arrest-how-can-doctors [cited 2020 April].

24. Cunha J. Remdesivir (RDV). RxList; https://www.rxlist.com/ consumer_remdesivir_rdv/drugs-condition.htm [cited 2020 April]; 2020.

25. Derebail VK, Falk RJ. ANCA-Associated Vasculitis-Refining Therapy with Plasma Exchange and Glucocorticoids. Mass Medical Soc. 2020;382(7):671-673. PMID: 32053306. Available from: https://doi.org/10.1056/NEJMe1917490.

26. Barbisch D, Koenig KL, Shih FY. Is there a case for quarantine? Perspectives from SARS to Ebola. Disaster medicine and public health preparedness. 2015;9(5):547-553. PMID: 25797363. Available from: https://doi.org/10.1017/dmp.2015.38.
27. Chiang JJ, Cole SW, Bower JE, Irwin MR, Taylor SE, Arevalo $J$, et al. Depressive symptoms and immune transcriptional profiles in late adolescents. Brain, behavior, and immunity. 2019;80:163-169. PMID: 30851376. Available from: https: //doi.org/10.1016/j.bbi.2019.03.004.

28. Liem A, Wang C, Wariyanti Y, Latkin CA, Hall BJ. The neglected health of international migrant workers in the COVID-19 epidemic. The Lancet Psychiatry. 2020;7(4):e20. Available from: https://doi.org/10.1016/S2215-0366(20)30076-6.

29. Zitting KM, Münch MY, Cain SW, Wang W, Wong A, Ronda JM, et al. Young adults are more vulnerable to chronic sleep deficiency and recurrent circadian disruption than older adults. Scientific reports. 2018;8(1):1-14. PMID: 30038272. Available from: https://doi.org/10.1038/s41598-018-29358-X.

30. Jia X, Zhang P, Tian Y, Wang J, Zeng H, Wang J, et al. Clinical significance of IgM and IgG test for diagnosis of highly suspected COVID-19 infection. medRxiv. 2020;Available from: https://doi.org/10.1101/2020.02.28.20029025.

31. Suo T, Liu X, Guo M, Feng J, Hu W, Yang Y. ddPCR: a more sensitive and accurate tool for SARS-CoV-2 detection in low viral load specimens. medRxiv. 2020;Available from: https: //doi.org/10.1101/2020.02.29.20029439.

32. Inovio IP. Inovio selected by cepi to develop vaccine against new coronavirus inovio, http://ir.inovio.com/news-and-med $\mathrm{ia} /$ news/press-release-details/2020/Inovio-Selectedby-CEPI -to-Develop-Vaccine-Against-NewCoronavirus/default.aspx [cited 202029 January]; 2020.

33. Johnson J. Our COVID-19 Response Efforts; https://www.jnj.c om/coronavirus [cited 202017 April]; 2020.

34. Gao Q, Bao L, Mao H, Wang L, Xu K, Li Y, et al. Rapid development of an inactivated vaccine for SARS-CoV-2. bioRxiv. 2020;Available from: https://doi.org/10.1101/2020.04. 17.046375.

35. Mestrovic T. PiCoVacc vaccine candidate for COVID-19 effective in animal trials News Medical Life Sciences; https://www .news-medical.net/news/20200421/PiCoVacc-vaccine-candi date-for-COVID-19-effective-in-animal-trials.aspx [cited 2020 May]; 2020.

36. Kazmi A, Khan MA, Ali H. Biotechnological approaches for production of bioactive secondary metabolites in Nigella sativa: an up-to-date review. International Journal of Secondary Metabolite. 2019;6(2):172-195. Available from: https://doi. org/10.21448/ijsm.575075.

37. Kazmi A, Khan MA, Mohammad S, Ali A, Ali H. Biotechnological Production of Natural Calorie Free Steviol Glycosides in Stevia rebaudiana: An Update on Current Scenario. Current Biotechnology. 2019;8(2):70-84. Available from: https: //doi.org/10.2174/2211550108666191210100751.

38. Tao Z, Yang Y, Shi W, Xue M, Yang W, Song Z, et al. Complementary and alternative medicine is expected to make greater contribution in controlling the prevalence of influenza. BioScience Trends. 2013;7(5):253-256. PMID: 24241177. Available from: https://doi.org/10.5582/bst.2013.v7.5.253.

39. Daily C. 6 effective TCM recipes for COVID-19, http://covid-19 .chinadaily.com.cn/a/202003/24/WS5e795bb6a3101282172 816c2.html [cited 2020 April]; 2020.

40. Han Y, Zhao M, Shi B, Song Z, Zhou S, He Y. Application of integrative medicine protocols on treatment of coronavirus disease 2019. Chin Tradit Herb Drugs. 2020;2020:02-18.

41. Yangxin S. Summary Report on Lianhua Qingwen Capsule/Granule for the Treatment of Influenza, Cold and Coronavirus Disease 2019 (COVID-19), http://en.yiling.cn/ylen/con tents/2204/226.html; 2020. 